\title{
Central Bank Challenges in the Global Economy
}

\author{
Fabian Amtenbrink
}

\section{Introductory Remarks}

There are few institutions linked to the exercise of public power in the economic sphere that have stood the test of time for as long as central banks. ${ }^{1}$ Indeed their origins can be traced back to the seventeenth century when in 1668 the Swedish 'Bank of the Estates of the Realm' the forerunner of todays Riksbank was established by the Riksdag, at the dawn of two major armed conflicts with neighbouring Denmark. Soon thereafter, in the midst of the Nine Year War between England and France the Bank of England was established by an Act of Parliament. ${ }^{2}$ Other European countries such as France and the German Reich would follow suit in due course. ${ }^{3}$

Asserting that the role of central banks has changed in the course of their long history is hardly original. These changes can be observed both with regard to their main tasks, as well as their ownership and (corporate) institutional structure. A number of central bank systems have emerged from private corporations ((joint-) stock companies) that were initially set up with the aim to raise capital for the financing of wars thus acting as the quasi-banker of government, while at the same time undertaking commercial banking. ${ }^{4}$ Eventually these banks would become public corporations. ${ }^{5}$ Other banks were set up as public corporations from

\footnotetext{
${ }^{1}$ Generally with regard to the development of central banking, see Siklos, The Changing Face of Central Banking, 2002.

${ }^{2}$ The Bank was founded under the title 'The governor and Company of the Bank of England' and granted royal charter on 27 July 1694.

${ }^{3}$ The Banque de France was set up in 1800 , whereas in the German Reich the Reichsbank, the forerunner of the Bundesbank, was only established in 1875 .

${ }^{4}$ Namely in Sweden, England and the Netherlands.

${ }^{5}$ Such as the Bank of England and De Nederlandse Bank.

F. Amtenbrink

Professor of European Union Law, Department of European Law, Eramus School of Law, Erasmus University Rotterdam, Burg. Oudlaan 50, P.O. Box 1738, 3000 DR Rotterdam, The Netherlands e-mail: amtenbrink@frg.eur.nl
} 
the start. ${ }^{6}$ The modification of the structure of the banks can be linked to the evolution of their tasks. Initially often set up to functioning as commercial entities they would eventually be charged with the issuing of currency and take on lender of last resort functions. Central banks became responsible for the conduct of monetary policy, albeit initially often subject to direct government supervision.

The principal role of central banks in the conduct of economic policy of a country also explains to some extent the trend towards nationalization of these institutions that can be observed namely in the first half of the twentieth century. However, a considerable number of central banks, including most prominently the Banks of the Federal Reserve System remain shareholder-owned. ${ }^{7}$ The legal bases of central banks reflected this function essentially by defining and delimiting the exercise of authority in line with what can be observed for other institutions that exercise public power. The definition of monetary policy objectives and the institutional structure of the bank, including the relationship with government, became central features of central bank legal bases. As the sole issuers of currency, certainly from the second half of the last century central banks also had a role to play beyond the national sphere mainly through foreign exchange rate operations and the participation in different international organizations and fore, such as the International Monetary Fund, the Bank for International Settlements and, more recently, the G-8 and G-20 summits.

When reflecting on the changing role of central banks in the global economy three interconnected developments can be observed, including globalization, regionalization and the global financial crisis. The hypothesis at the outset is that these developments which are to a considerable extent beyond the sphere of influence of any one central bank or indeed national government can have a decisive impact on the (constitutional) legal position of central banks and their foremost task, as it is currently understood, that is the conduct of monetary policy. This contribution offers a panoramic view of selected issues linked to the institutional position and main monetary policy task(s) of central banks and thus does not aim at an all inclusive legal and/or economic analysis of all tasks that are or odd to be associated with central banking.

\section{Globalization}

In the context of economic developments globalization may refer to "... the processes involved with the emergence of a global economy characterized not only by the opening of markets and the rapid expansion of trade, but moreover

\footnotetext{
${ }^{6}$ Such as the Reichsbank, the forerunner of the German Bundesbank.

${ }^{7}$ The South African Reserve Bank may serve as an example of a shareholder-owned central bank whose status has recently come under pressure. See Press release on the nationalization of the South African Reserve Bank of 25 January 2010, available at http://www.reservebank.co.za (last accessed 7 May 2010).
} 
also of the removal of financial market restrictions and free capital flow on a global scale." 8 Capital flow takes on namely the shape of Foreign Direct Investment leading "... to an internationalisation of production processes and new ways of doing business as companies have established affiliates abroad both to gain access to foreign markets and to reduce input costs." "Central banks face several challenges. Firstly, there is an increased pressure to bring national laws and practices relating to macro-economic governance in line with internationally recognised standards and best practice. Moreover the regional pooling of monetary policy tasks has resulted in a reformulation of the missions of central banks.

\section{Towards Global Standards and Practices}

Ohler has pointed out rightly that "From a legal point of view, the existence of internationally open markets is surprising insofar as there exist no relevant treaty rules under international law imposing a general obligation on states to guarantee free movement of capital", pointing furthermore out that states “... unilaterally opened their capital markets, mainly to attract direct investments but also in order to benefit from other forms of international capital movements." ${ }^{10}$ Along equal lines it may be argued that there is no international legal obligation to introduce particular institutional arrangements with regard to monetary policy. Nevertheless a remarkable synchronization of law and practice can be witnessed with regard to monetary policy. Somewhat pointed central banks can be characterised as being independent and single minded.

The reason for this partially spontaneous harmonization is that capital can move virtually free of restrictions and, given today's technological advances, can be relocated almost instantly. Failing to bring law and practice on macro-economic governance in line with internationally recognised standards and best practice can result in a loss of confidence of globally acting markets in the financial environment of a country at the detriment in the medium-term also of the real economy. Global competition arguably reveals systemic weaknesses also in the legal sphere. It may thus not be surprising that in parallel to the globalization of financial markets also the main contours of monetary policy and the institutions that are charged with its conduct have become less distinct. In fact, a clear monetary policy objective geared towards the combating of inflation has become the dominant feature of central banks. On the institutional side, central bank independence and accountability have

\footnotetext{
${ }^{8}$ Amtenbrink/Lastra, Securing Democratic Accountability of Financial Regulatory Agencies A Theoretical Framework, in: De Mulder (ed.), Mitigating Risk in the Context of Safety and Security. How Relevant Is a Rational Approach?, 2008, p. 5 (5).

${ }^{9}$ Trichet, The Role of Central Banks in a Globalized Economy, Speech held on the occasion of the 13th Conference de Montréal, 18 June 2007, p. 1.

${ }^{10}$ Ohler, International Regulation and Supervision of Financial Markets After the Crisis, Working Papers on Global Financial Markets No. 4, March 2009, p. 9.
} 
become two almost globally recognised standards of central bank governance and indeed prerequisite for the credibility of a countries' monetary policy. ${ }^{11}$ The existence of this peer pressure to fall in line is verified by the fact that countries lacking a credible monetary policy choose to unilaterally link their currency to that of a country or region with a central bank system featuring such characteristics. ${ }^{12}$ The benefits resulting from a managed or fixed exchange rate regime (currency pegging) are thought to outweigh the costs of losing monetary policy as an (ineffective) tool of economic policy. ${ }^{13}$

Facilitating this process of de jure synchronization, central bank governance issues, ranging from the legal foundations and accountability to operational issues, are regularly discussed in international fora, such as the Central Bank Governance Forum, ${ }^{14}$ the Central Bank Governance Network, ${ }^{15}$ and the International Monetary Fund (IMF). This has resulted in standard-setting, such as the 1999 IMF Code of Good Practices on Transparency in Monetary and Financial Policies. Rather than to establish a model central bank law the Code defines legal principles and rules of conduct covering responsibilities and objectives of central banks for monetary policy; the openness of the process for formulating and reporting monetary policy decisions, as well as the public availability of information on monetary policy; accountability arrangements for central banks. ${ }^{16}$ While this Code is of a nonbinding nature, it does not only reflect the major legal characteristics of many central banks today but has also been applied in drawing up new or modernising existing central bank systems, not least as a result of advisory activities of the IMF, such as in the case of the 2004 Central Bank of Iraq Law. ${ }^{17}$

\footnotetext{
${ }^{11}$ Amtenbrink, The Three Pillars of Central Bank Governance - Towards a Model Central Bank Law or a Code of Good Governance?, in: International Monetary Fund, Current Developments in Monetary and Financial Law, Vol. 4, 2005, pp. 101 et seq. (102 et seq.).

${ }^{12}$ Currency board arrangements can for example be observed in a number of countries both inside and outside the EU, including Bulgaria and Bosnia and Herzegovina. Kosovo and Montenegro are examples of countries which use the euro as a parallel currency without any formal monetary agreements with the EU.

${ }^{13}$ In context of the Euro, see Amtenbrink, Bits of Economic and Monetary Union Everywhere, in: Kochenov (ed.), On Bits of Europe Everywhere. Overseas Possessions of the EU Member States in the Legal-Political Context of European Law, forthcoming.

${ }^{14} \mathrm{~A}$ selected group of central bank governors that exchange views on the design and operation of central banks.

${ }^{15}$ Forum bringing together central bank governors to exchange views on issues of central bank governance with the Bank for International Settlements.

${ }^{16}$ IMF, Code of Good Practices on Transparency in Monetary and Financial Policies: Declaration of Principles, 1999, available at http://www.imf.org (last accessed 7 May 2010). On the feasibility of a model central bank law (blueprint) see Amtenbrink, The Three Pillars of Central Bank Governance - Towards a Model Central Bank Law or a Code of Good Governance?, in: International Monetary Fund, Current Developments in Monetary and Financial Law, Vol. 4, 2005, pp. 101 et seq. (119 et seq.).

${ }^{17}$ Law of 6 March 2004, available at http://www.cbi.iq/ (last accessed 7 May 2010). The IMF was heavily involved in the drawing-up of the new statute.
} 


\section{Central Banks as Guardians of Price Stability}

Generally speaking economic policy may be divided into fiscal policy and monetary policy. The latter is generally vested in the central bank of a country which regulates the money supply, as well as the availability (liquidity) and cost of money ${ }^{18}$ (interest rates) namely through open market operations (mainly refinancing operations), standing facilities (overnight lending and deposit facilities) and minimum reserve requirements for financial institutions. ${ }^{19}$

In pursuing monetary policy central banks are bound by the objectives which their legal bases set. Such objectives may in principle refer to a whole range of developments including inflation, employment and economic growth. A trend can be observed towards the establishment of a singular monetary objective geared towards price stability. With regard to the latter, the insights into what monetary policy can and more importantly cannot achieve has developed towards the mainstream conviction that the long-term impact of monetary policy on the real economy and namely growth and employment is limited (the so-called neutrality of money), ${ }^{20}$ whereas at the same time a low rate of inflation forms the basis for and has a favourable effect on real growth and employment. ${ }^{21}$ This is reflected in many modern central bank legal bases which identify price stability as the primary monetary policy objective.

This is not to say however that price stability is in all instances the only or indeed primary monetary objective with which central banks are entrusted. While there has been a clear trend towards giving priority to the combat of inflation, ${ }^{22}$ some central bank legal bases still include multiple objectives. In the case of the European Central Bank (ECB), Art. 127(1) TFEU clearly states that the primary objective of the Bank is to maintain price stability. While the European System of Central Banks (ESCB) is also supposed to support the general economic policies in the Union, this is limited by the fact that such activities may not compromise the primary objective of the ECB. In cases where legal bases do introduce multiple objectives in practice some central banks nevertheless orient their monetary policy towards price stability. The Norges Bank, the central bank of Norway may serve as an example in this regard. Monetary policy is supposed to be geared towards the

\footnotetext{
${ }^{18} \mathrm{~A}$ broad concept of money is referred to here which does not only include banknotes and coins but also other means of payment, see Mitlid/Vesterlund, Steering interest rates in monetary policy how does it work, Sveriges Riksbank Economic Review (2001) 1, p. 19.

${ }^{19}$ As this contribution focuses on the monetary policy objective itself, policy instruments are not discussed here.

${ }^{20}$ See e.g. European Central Bank, The Monetary Policy of the ECB, 2004, pp. 41-42.

${ }^{21}$ See e.g. Issing, Why Price Stability?, Paper presented at the First ECB Central Banking Conference on 2 and 3 November 2000, available at http://www.ecb.int (last accessed 7 May 2010), with further references to relevant economic literature.

${ }^{22}$ Another example for a major central bank with a single monetary policy objective of price stability is the Bank of Japan. See Art. 2 of the Bank of Japan Act (Act No. 89 of 18 June 1997). The English language version is available at http://www.boj.or.jp/en/ (last accessed 7 May 2010).
} 
stability of the Norwegian krone's national and international value and, at the same time, must underpin fiscal policy by contributing to stable developments in output and employment. The Norges Bank has translated this into an operational target geared towards low and stable inflation. ${ }^{23}$ Somewhat in contrast to this approach, based on indistinct and multiply statutory monetary objectives, the Federal Reserve System (FED) and namely its Board of Governors and Federal Open Market Committee conducts a monetary policy that promotes the achievement of the statutory objectives of stable prices and maximum employment. ${ }^{24}$

As to the quantification of the monetary policy objective of central banks and thus the degree to which and by whom the primary task of the central bank is demarcated, different arrangements can be observed. Regularly the legal basis of a central bank will not define the monetary objective namely through a quantification of the price stability criterion. Highlighting this point, neither the Statute of the ESCB and of the ECB nor the Federal Reserve Act include any details in this regard. $^{25}$ At the same time, the degree to which central banks are free in defining price stability varies. Some legal bases foresee in a procedure for the establishment of policy targets unilaterally by government, such as in the case at the Bank of England, ${ }^{26}$ or by means of an agreement between government and the central bank, such as for example at the Reserve Bank of New Zealand. ${ }^{27}$ In other instances, most notably the ECB and the FED, it is effectively left to the central bank itself to quantify the monetary policy objective(s). Leaving aside the question whether from the point of view of accountability a central bank should indeed be in charge of setting its own goal(s), ${ }^{28}$ there is a notable consistency in the approach by central

\footnotetext{
${ }^{23}$ See paragraph 1 of the Regulation on Monetary Policy established by Royal Decree of 29 March 2001 pursuant to section 2, third paragraph, and section 4, second paragraph, of the Act of 24 May 1985 no. 28 on Norges Bank and the Monetary System.

${ }^{24}$ See section 2A(1) of the Federal Reserve Act: "The Board of Governors of the Federal Reserve System and the Federal Open Market Committee shall maintain long run growth of the monetary and credit aggregates commensurate with the economy's long run potential to increase production, so as to promote effectively the goals of maximum employment, stable prices, and moderate longterm interest rates." Also see the goals of the FED as defined in the Board of Governor's Planning Document 2008-2011, available at http://www.federalreserve.gov (last accessed 7 May 2010). With regard to the approach to monetary policy in practice see Federal Reserve Bank San Francisco, A Primer on Monetary Policy Part I: Goals and Instruments, FRBSF Weekly Letter, Number 94-27, 5 August 1994.

${ }^{25}$ With regard to the ECB see Art. 127(1) TFEU. With regard to the FED see memorandum submitted by the United States Federal Reserve System, in Treasury and Civil Service Committee, The Role of the Bank of England, House of Commons Paper. Session 1993-94; 98-I vol. 2), Report, together with the proceedings of the Committee, HC Session 1993-94 (HMSO, London 1993), app. 20.

${ }^{26}$ See section 12(1) of the Bank of England Act 1998. In practice the Chancellor of the Exchequer sets an inflation target to be pursued by the Bank.

${ }^{27}$ See section 9 Reserve Bank Act 1989 based on which government and the governor of the Bank have to establish a so-called Policy Target Agreement (PTA).

${ }^{28}$ On this issue see Amtenbrink, The Democratic Accountability of Central Banks, 1999, chapter 5 I.1.1.
} 
banks to the setting of inflation targets. ${ }^{29}$ Thus for example the ECB aims at keeping an inflation rate of below, but close to $2 \%$ over the medium term, the most recent inflation target of the Bank of England is set at 2\%, the Norge Bank targets a consumer price inflation of approximately $2.5 \%$ over time, and the latest Policy Target Agreement applicable to the Reserve Bank of New Zealand sets an inflation rate between $1 \%$ and $3 \%$ on average over the medium term. Despite multiply and non-hierarchical monetary policy objectives even FED officials in the past signalled towards a rate in the region of $3 \% .^{30}$

\section{Central Bank Independence and Accountability}

Similar to the price stability objective, central bank independence has become an important pillar of central bank governance that has found its way in many central bank legal bases and thus characterises many central bank systems. Based on insights from political economy in the last decades there has been a remarkable trend towards the removal of monetary policy from the political business cycle by positioning central banks outside the trias politica. ${ }^{31}$

This trend is closely linked to the attainable aims of monetary policy described in the previous section. Indeed, it has been observed that there is a link between the institutional structure of a central bank and namely its degree of independence and the extent to which it can pursue monetary policy effectively, as "... an independent central bank can give full priority to low levels of inflation, whereas in countries with a more dependent central bank other considerations (notably reelection perspectives of politicians and a low level of unemployment) may interfere with the objective of price stability." 32 Monetary temptations by politicians can stand in the way of an inflation-adverse monetary policy and long-term stability.

\footnotetext{
${ }^{29}$ In defends of the ECB's approach in this regard this was already noted by Duisenberg, The ECB's quantitative definition of price stability and its comparison with such definitions or inflation targets applied in other large economic areas, Letter to the Chairperson of the Committee on Economic and Monetary Affairs, Mrs. Christa Randzio-Plath, available at http://www.ecb.int (last accessed 7 May 2010).

${ }^{30}$ Greenspan, Opening Remarks to the symposium "Achieving Price Stability", sponsored by the Federal Reserve Bank of Kansas City, 29-31 August 1996, pp. 1-5, available at http://www.kc.frb. org (last accessed 7 May 2010).

${ }^{31}$ For a recent study with further references to economic literature see Crowe/Meade, Central Bank Independence and Transparency: Evolution and Effectiveness, IMF Working Paper WP/08/119.

${ }^{32}$ De Haan/Amtenbrink/Eijffinger, Accountability of Central Banks: Aspects and Quantifications, BNL Quarterly Review, no. 209 - June 1999, pp. 169 et seq. (169-170), with reference to Cuckierman, Central Bank Strategy, Credibility and Independence, 1992. For a more recent study, see Alpanda and Honing, Political Monetary Cycles and a de facto Ranking of Central Bank Independence, SSRN Working Paper June 2009, available at http://papers.ssrn.com/sol3/ papers.cfm?abstract_id=1032084 (last accessed 7 May 2010).
} 
A monetary policy directed towards low levels of inflation is considered to be more credible. This in return will enhance the effectiveness of the policy conducted by the central bank. Indeed, ample evidence has been provided in economic writing for a negative correlation between central bank independence and inflation and inflation variability. ${ }^{33}$ Similar arguments are also applied to financial regulatory and supervisory authorities, as the distance of the latter from government and elected politicians is considered a precondition for the effective conduct of its task, namely banking supervision. ${ }^{34}$ These insights have translated into the character of the legal bases of central banks which define the position of the monetary policy authority outside government namely by establishing own legal personality, the freedom to pursue statutorily prescribed objectives and to apply the available instruments more or less insulated from government or parliamentary interventions and by establish the financing of the central bank through own resources. ${ }^{35}$ Moreover, this also includes the exclusion or limitation of central bank credit to government. ${ }^{36}$

While in most instances central bank legal bases have the status of an ordinary law (act of parliament), in the case of the European System of Central Banks this feature has been elevated to a quasi-constitutional status, as the TFEU ensures the independence not only of the European Central Bank (ECB), but also of the participating national central banks in the conduct of the tasks assigned to them in the ESCB. ${ }^{37}$ Vesting monetary policy and thus, an important part of economic policy outside government and with it the constitutional system of checks and balances applicable thereto has raised concerns about the accountability of central banks for the tasks that have been assigned to them, and namely the pursue of the monetary policy objectives. ${ }^{38}$ Indeed, a central bank that continuously pursues a monetary policy which lacks broad political support but also the support of the public at large is likely to be overridden sooner or later. ${ }^{39}$ Conversely, a broad public support can help to shield a central bank from political pressure. As a

\footnotetext{
${ }^{33}$ See Eijffinger/De Haan, The Political Economy of Central-Bank Independence, Princeton University Special Papers in International Economics, No. 19, May 1996, with further references.

${ }^{34}$ See e.g. Basle Committee of Banking Supervisors, Principles for Effective Banking Supervision, September 1997, List of core principles for effective banking supervision, para. 1.

${ }^{35}$ Different elements refer to the institutional, functional, organizational and financial independence of a central bank.

${ }^{36}$ See e.g. Cottarelli, Limiting Central Bank Credit to the Government. Theory and Practice, IMF Occasional Paper No. 110, December 1993, pp. 3 et seq. In the context of the ESCB see Art. 123-124 TFEU.

${ }^{37}$ Art. $130-131$ TFEU and the Protocol on the ESCB and of the ECB annexed to EU Treaty and TFEU; see also Art. 88 of the German Basic Law (Grundgesetz) which makes the transfer of monetary policy competences subject to the existence of a ECB that is independent and moreover geared towards maintaining price stability.

${ }^{38}$ See e.g. Gormley/De Haan, The Democratic deficit of the European Central Bank, ELRev. 21 (1996), p. 95; Amtenbrink, The Democratic Accountability of Central Banks, 1999, with further references.

${ }^{39}$ De Haan/Amtenbrink/Eijffinger, Accountability of Central Banks: Aspects and Quantifications, BNL Quarterly Review, no. 209, June 1999, pp. 169 et seq. (171).
} 
counterweight to the independent position of central banks, in the last two decades drafters of central bank legislation have become more alert to introduce channels through which the central bank is answerable for its conduct. In general, mechanisms providing those charged with judging the performance of the bank with the necessary means to make an informed assessment and tools to penalize central bank behaviour can be differentiated. In judging the performance of a central bank first and foremost its primary monetary policy objective must be defined as precisely as possible. The trend described in the previous section to identify price stability as an overriding objective in many central bank laws has facilitated the accountability of central banks. At the same time considerable differences exist with regard to the extent to which and by whom the objective is actually quantified. Central bank legal bases regularly impose specific information obligation and thus, transparency requirements. The purpose of these requirements at least in practice is twofold, as they may not only serve the accountability, but also the credibility of the central bank. $^{40}$

At the same time, central bank laws and namely those that provide for a large degree of independence often do not include elaborate provisions linked to penalizing central bank action. This is hardly surprising given the potential trade-off between independence and arrangements such as overriding mechanism allowing for monetary policy decisions to be (temporarily) set aside and the possibility for a performance-based dismissal of central bank officials. To be sure this is not to say that there is no room for such arrangements, as the example of internationally recognized central bank systems, such as the Federal Reserve Bank of New Zealand and the Bank of England, highlight. ${ }^{41}$

\section{Regionalization}

An important factor contributing to the unification of the position and tasks of central banks certainly in the European context has been regionalization. Despite several examples of regional cooperation of countries in the economic sphere, such as inter alia the North American Free Trade Agreement (NAFTA), the Association of Southeast Asian Nations (ASEAN) and the Common Market of the South (MERCOSUR), ${ }^{42}$ undoubtedly the European Union (EU) is the most far-reaching

\footnotetext{
${ }^{40}$ Dincer/Eichengreen, Central Bank Transparency: Where, Why and With What Effects?, NBER Paper No. 13003, March 2007; De Haan/Amtenbrink/Waller, The Transparency and Credibility of the European Central Bank, JCMS 42 (2004) 4, p. 775, with further references.

${ }^{41}$ The Reserve Bank of New Zealand Act 1989 introduces both an override mechanism and performance-based dismissal of the governor of the Bank. The possibility to override monetary policy decisions can also be found at the Bank of England under the Treasury's reserve powers, see section 19 of the Bank of England Act 1998.

${ }^{42}$ See e.g. Hochreiter/Schmidt-Hebbel/Winckler, Monetary Union: European Lessons, Latin American Prospects, The North American Journal of Economics and Finance 13 (2002) 3, p. 297.
} 
form of regional integration, not least because it also stands for an advanced, albeit far from optimal, system of macroeconomic coordination and monetary policy integration.

Other monetary cooperations are of a geographically and economically limited nature, namely the Union économique et monétaire ouest-africaine (UEMOA) ${ }^{43}$ with the Banque centrale des Etats de l'Afrique de l'Ouest (BCEAO) being entrusted with the conduct of monetary policy of Benin, Burkina Faso, Côte d'Ivoire, Guinea-Bissau, Mali, Niger, Sénégal and Togo, and the Communauté économique et monétaire de l'Afrique Centrale (CEMAC) ${ }^{44}$ with the Banque des Etats de l'Afrique centrale (BEAC) being in charge of monetary policy for Cameroon, Central African Republic, Chad, Republic of Congo, Equatorial Guinea and Gabon. Both common currencies, that is the UEMOA Western African CFA franc and the CEMAC Central African CFA franc are convertible through a fixed parity initially with the French franc (now the Euro) based on bilateral agreements. ${ }^{45}$

In contrast, the EU stands for an unprecedented degree not only of legal and economic, but also political and social integration of countries and their citizens. The 1957 Treaty establishing a European Economic Community (EEC Treaty) did not only lay the foundations for the free movement of financial services, the freedom of establishment of financial institutions in all Member States and the free movement of capital, ${ }^{46}$ but also already provided the basic rationale for the abolishing of barriers to trade arising from the utilization of each Member State of their own currency. ${ }^{47}$ It may thus be little surprising that already in 1970 plans where pursued in the then European Communities to establish a Community system of central banks and to irrevocably fix the exchange rates of the currencies of the Member States. ${ }^{48}$ Ironically, these plans for the establishment of a European economic and monetary union in stages became victim of the global economic

\footnotetext{
${ }^{43}$ Treaty establishing the West African Monetary Union (WAMU) signed on 12 May 1962 (as amended), namely Title V.

${ }^{44}$ Traité du 16 mars 1994 instituant la Communauté Economique et Monétaire de l'Afrique Centrale.

${ }^{45}$ On the efforts of the UEMOA and CEMAC to promote the convergence of economic policies see Strauss-Kahn, Regional Currency Areas: A Few Lessons from the Experiences of the Eurosystem and the CFA Franc Zone, BIS Papers No. 17, supra n. 51, pp. 43-58 (p. 51).

${ }^{46}$ To be sure, free movement of capital was only fully liberalized in primary European law with the coming into effect of the new provisions on capital in the Treaty on the European Union. Prior to that restrictions on movements of capital had already been abolished by secondary Community law, see Council Directive 88/361/EEC of 24 June 1988 for the implementation of Article 67 of the Treaty, OJ 1988 L 178/5, and namely the nomenclature in its Annex 1.

${ }^{47}$ Inter alia in the shape of exchange rate risks and a lack of price transparency in the internal market.

${ }^{48}$ Report to the Council and Commission on the Realisation by Stages of Economic and Monetary Union in the Community of 8 October 1970, OJ 1970 C 136/1. This document has become better known as the Werner Report.
} 
crisis and the collapse of the first and until the present day only global exchange rate system under the Bretton-Woods Agreement, the so-called Gold Standard, ${ }^{49}$ leaving the Member States without any effective coordination of their exchange rates until the establishment of the European Monetary System.

The provisions on Economic and Monetary Union (EMU) introduced by 1993 Treaty on European Union highlight how the role of national central banks can change in the process of the pooling of competencies for monetary policy in a single institutional framework and the replacement of the national currencies by a single common currency. It would be an oversimplification to describe this process as one of centralization of monetary policy. Instead an institutional system has been put in place which, as far as its decision-making structure is concerned, shares some characteristics of federal central bank systems, such as the German Bundesbank and the FED. ${ }^{50}$ While monetary policy decisions are no longer taken at the national central banks, their governors - for the time being - all participate in the decisionmaking in the Governing Council, the decision-making body of the ECB. ${ }^{51}$ Due to this involvement of the national central bank governors in the decision-making of the independent ECB, primary Union law extends the independence requirement also to the national central banks of the Member States. Resulting from this, in the run-up to EMU, several central bank laws of the Member States where amended to bring them in line with the provisions of the then EC Treaty (now TFEU) and the Statute of the ESCB and of the ECB.

As a consequence of the pooling of competences in the area of monetary policy the central banks of the euro area Member States were effectively stripped of their primary task and - at least in some instances - also their dominant position in the national system of economic governance. ${ }^{52}$ In seeking new areas of activities, not least in order to limit cuts - central banks have taken on new or expanded on existing tasks not linked to those exercised in the framework of the ESCB. In particular with regard to financial markets and namely financial institutions central banks can be seen to fulfil prudential supervisory tasks either on their own or jointly with other national agencies.

\footnotetext{
${ }^{49}$ See Articles of Agreement of the International Monetary Fund of 2 July 1944, as amended.

${ }^{50}$ It is a well-known fact that namely the Bundesbank-system has been a major source of inspiration for the drafters of the legal framework governing the ESCB and the ECB.

${ }^{51}$ Note that according to Art. 10(2) of the Statute of the ESCB and of the ECB a voting system on a rotation basis is introduced from the time that the number of national central bank governors present in the Governing Council exceeds 15 . The introduction of this system has been postponed until the number of national central bank governors exceeds 18. See Decision of the ECB of 18 December 2008 to postpone the start of the rotation system in the Governing Council of the European Central Bank, ECB/2008/29, OJ 2009 L 3/4.

${ }^{52}$ In the case of Germany it is fair to extent this previous position to Europe as a whole, see Marsh, The Bundesbank. The Bank that Rules Europe, 1993.
} 
What is more, the establishment of a European regional currency unit has become a model for initiatives in the same direction elsewhere. Thus for example the participating countries in the Gulf Cooperation Council, including Bahrain, Kuwait, Oman, Qatar, Saudi Arabia and the United Arab Emirates have announced plans to launch a single currency. ${ }^{53}$

\section{Global Challenges to Central Banking}

In the economic and monetary sphere fiscal and monetary policy authorities find themselves faced with developments which are not only outside their sphere of influence, but at times also difficult to anticipate. While the global financial crisis may be considered the prime example in this regard, the same also holds true under normal conditions in the global economy.

\section{The Globalization of Monetary Policy}

The challenges which central banks face in the light of globalization and also regionalization are not only of an institutional nature, but also concern the monetary policy tasks they perform. More concrete, central banks are faced with economic developments outside their sphere of influence. It has been highlighted that globalization increases uncertainty for monetary policy and evidence has been provided to the effect that central banks have become less effective in influencing national liquidity conditions. ${ }^{54}$ Whether and to what extent central banks should pursue a monetary policy that is more geared towards taking into account possible spill-over effects as a result of global financial markets is arguably not primarily a legal question in the sense that this does not require an adjustment of the legal basis of a central bank, but rather of the monetary policy strategy pursued by the central bank. Given their independent position, this is primarily for the central bank itself to decide upon.

However, does globalization have an influence on the central bank in pursuing its primary/main monetary policy objective in the first place? With the opening of markets global developments namely linked to the trade in goods and services have an impact on the development of prices. Both positive and negative effects can be

\footnotetext{
${ }^{53}$ See Sturm and Siegfried, Regional Monetary Integration in the Member States of the Gulf Cooperation Council, ECB Occasional Paper Series No. 31, June 2005; see also Malliaris, The Global Monetary System: Its Weaknesses and the Role of the IMF, the EU and NAFTA, North American Journal of Economics and Finance 13 (2002), pp. 72 et seq.

${ }^{54}$ See e.g. the study by Belke/Rees, The Importance of Global Shocks for National Policy Makers. Rising Challenges for Central Banks, Ruhr Economic Papers No. 135, September 2009, who identify global liquidity as an important factor.
} 
linked to this globalization of inflation. ${ }^{55}$ On the one hand, globalization is considered to have had a positive effect on inflation in industrial countries by inducing downward pressure on prices inter alia through the opening of labour markets, better allocation of (financial) resources and increased competition. ${ }^{56}$ However, highlighting the complexity of the effects of the processes involved, globalization may also induce upward pressure on prices as demand namely for energy and raw materials in emerging economies has grown notably. Whether and to what extent a positive correlation between globalization and inflation exists in the long-run remains subject of debates. Summarizing the scepticism raised against the globalization-of-inflation argument Ball argues: "In my view, there is little reason to think that globalization has influenced inflation significantly. "Modest" and "limited" probably overstate the effects." 57

Trichet has observed that "Whatever the influences being exerted in the context of globalisation, the basic principle which allows the anchoring of monetary policy remains: in the long run, inflation is a monetary phenomenon. As a consequence, globalisation does not affect the central role and overriding responsibility of central

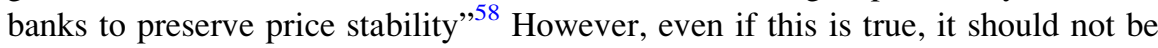
mistaken for an argument that globalization cannot have an impact on the policy stands of a central bank. While in the absence of exchange rate arrangements central banks continue to decide themselves on the rate of inflation of their currency, ${ }^{59}$ in determining their approach to monetary policy and thus their strategy monetary policy authorities do need to take into account the "global factors [that] drive inflation" and thus the external factors that put pressure on prices. ${ }^{60}$ What is more, the aftermath of the global financial crisis highlights that external and

\footnotetext{
${ }^{55}$ Generally see International Monetary Fund, Globalization and Inflation, World Economic Outlook, April 2006.

${ }^{56}$ See e.g. Rogoff, Impact of Globalization on Monetary Policy, Paper prepared for the symposium sponsored by the Federal Reserve Bank of Kansas City, August 2006, available at http://www.kc. frb.org/PUBLICAT/SYMPOS/2006/pdf/rogoff.paper.0829.pdf (last accessed 7 May 2010), pp. 6 et seq; but see Trichet, The Role of Central Banks in a Globalized Economy, Speech held on the occasion of the 13th Conference de Montréal, 18 June 2007, p. 4, who also refers to other contributing factors not directly linked to globalization, such as budgetary discipline and the anti-inflationary approach to monetary policy.

${ }^{57}$ Ball, Has Globalization Changed Inflation, NBER Working Paper No. 12687, November 2006, p. 1

${ }^{58}$ Trichet, The Role of Central Banks in a Globalized Economy, Speech held on the occasion of the 13th Conference de Montréal, 18 June 2007.

${ }^{59}$ A point made by Kohn, The Effects of Globalization on Inflation and Their Implications for Monetary Policy, Speech held at the Federal Reserve Bank of Boston's 51st Economic Conference, 16 June 2006, available at http://www.federalreserve.gov (accessed 7 May 2010).

${ }^{60}$ Brackets added. Rogoff, Impact of Globalization on Monetary Policy, Paper prepared for the symposium sponsored by the Federal Reserve Bank of Kansas City, August 2006, available at http://www.kc.frb.org/PUBLICAT/SYMPOS/2006/pdf/rogoff.paper.0829.pdf (last accessed 7 May 2010), p. 8; Ball, Has Globalization Changed Inflation, NBER Working Paper No. 12687, November 2006, p. 3, argues that financial openness as defined by the ratio of foreign assets and liabilities have an impact on interest rates and asset prices.
} 
asymmetric shocks can compel central banks to act in the face of a narrowly defined monetary policy objective.

In fulfilling their tasks in a globalized economy the margin of error for central banks are smaller than has previously been the case. Much more so than by any formal mechanisms of accountability vis-à-vis government and/or parliament, central banks are judged by their actions. Kohn observes in this context that "... integrated financial markets can exert powerful feedback, which may be less forgiving of any perceived policy error". 61 The author highlights this point with reference to the FED: "For example, if financial market participants thought that the FOMC was not dedicated to maintaining long-run price stability- a notion that I can assure you is not correct- they would be less willing to hold dollar-denominated assets, and the resulting decline in the dollar would tend to add to inflationary pressures." 62

While there are currently no concrete plans in this direction, the global financial openness and the risks of spill-over and domino effects linked thereto does raises the question whether new, reinforced forms of transnational economic and monetary governance are required. ${ }^{63}$ This has accumulated in calls for the establishment of a global monetary authority. ${ }^{64}$ Such far-reaching proposals may be a long way off, to say the least. Yet the above mentioned trend towards the regional pooling of monetary policy could, if continued, facilitate the rebirth of a global exchange rate mechanism to facilitate stability.

By pooling monetary policy as in the case of the ESCB and the ECB, an additional challenge arise if the transfer of competences with regard to monetary policy is not accompanied by a transfer of equal competences for the conduct of a common economic policy. In the EU economic policies remain to a large extent a domain of the Member States. This poses special challenges for the ECB in formulating and implementing monetary policy in the euro area. From the start it could be observed that economic developments of the euro area Member States were anything but homogenous, raising the question whether the EU or at least the euro area actually constitutes an optimal currency area. ${ }^{65}$ While the success of

\footnotetext{
${ }^{61}$ Kohn, The Effects of Globalization on Inflation and Their Implications for Monetary Policy, Speech held at the Federal Reserve Bank of Boston's 51st Economic Conference, 16 June 2006, available at http://www.federalreserve.gov (last accessed 7 May 2010).

${ }^{62} \mathrm{Kohn}$, The Effects of Globalization on Inflation and Their Implications for Monetary Policy, Speech held at the Federal Reserve Bank of Boston's 51st Economic Conference, 16 June 2006, available at http://www.federalreserve.gov (last accessed 7 May 2010).

${ }^{63}$ See e.g. the study by Belke/Rees, The Importance of Global Shocks for National Policy Makers. Rising Challenges for Central Banks, Ruhr Economic Papers No. 135, September 2009.

${ }^{64}$ See e.g. Garten, Global authority can fill financial vacuum, Financial Times Online edition, published on 25 September 2008, available at http://www.ft.com (last accessed 7 May 2010); Calvo, Lender of last resort: Put it on the agenda!, VoxEU.org Policy Note, 23 March 2009, available at http://www.voxeu.org (last accessed 7 May 2010).

${ }^{65}$ Issing, One size fits all! A single monetary policy for the Euro Area, Speech held at the International Research Forum, 20 May 2005; Amtenbrink, Economic, Monetary and Social Policy, in: McDonnell/Kapteyn/Mortelmans/Timmermans (eds.), The Law of the European Union and the
} 
monetary policy in such an asymmetric system of economic governance depends not in the least on strong legal mechanisms to ensure fiscal discipline of the participating Member States, the near de facto insolvency of the euro area Member State Greece highlights the severe shortcomings of the present system of economic coordination in the EU and the danger this poses for a unified monetary policy.

\section{The Global Economic Crisis}

The global financial crisis has highlighted the consequences and knock-on effects that the collapse of large financial institutions can have not only on the financial system but also on the real economy. While central banks arguably played a role both in the making of and dealing with this crisis of global proportions, it is arguably the former which has attracted the attention of legislators and policy makers the most, resulting in the re-assessment of the role of central banks. ${ }^{66}$

In analysing the causes of the global financial crisis the European Commission mandated 2009 Larosière Report identifies several causes including inter alia: the illusion that permanent and sustainable high level of growth are sustainable; fundamental failures in the evaluation of risk and the role that Credit Rating Agencies play with regard to the assessment of credit risk; a failure of corporate governance; a failure of the regulatory and supervisory system as well as of the crisis management. ${ }^{67}$ In this context also the role of central bank has been criticised for having contributed to 'benign macroeconomic conditions' through low interest rates which, combined with low inflation rates have resulted in a rapid growth of the volume of credit. Namely the role of the Fed has been questioned for its omission to tighten its monetary policy stands, thereby meeting excess liquidity namely in the shape of rapidly rising asset prices. In the view of experts this has contributed to the

European Communities, (4th ed.) 2008, pp. 881 et seq. (966), on early signs of diverging economic situations in the euro area.

${ }^{66}$ With regard to the role of central banks in dealing with the crisis that is not explored in this contribution, see e.g. Bank for International Settlements Committee on the Global Financial System, Central bank operations in response to the financial turmoil, Report submitted by a Study Group established by the Committee, July 2008, available at http://www.bis.org (last accessed 7 May 2010); Papademos, How to deal with the global financial crisis and promote the economy's recovery and sustained growth, Speech held at the 7th European Business Summit organised by the European Business Forum, 26 March 2009, available at http://www.ecb.int (last accessed 7 May 2010); Roth, Challenges for Central Banks during the Current Global Crisis, address at the occasion of the Sixth Annual NBP-SNB Joint Seminar on "Challenges for Central Banks during the Current Global Crisis", 15 June 2009, available at http://www.snb.ch/n/mmr/ reference/sem_2009_06_14_speech/source (last accessed 7 May 2010).

${ }^{67}$ The High-Level Group on Financial Supervision in the EU (Larosière Report), chaired by J. de Larosière, 25 February 2009, p. 7 et seq. To be sure, the policy recommendations made in this report are not all limited to the EU. 
housing bubble that is linked to the subprime mortgage crisis. ${ }^{68}$ The credibility of central banks has suffered as a result of this. Indeed, central banks have been diagnosed with a "doctrinal blindness", 69 and the rationale of the focus in many central bank systems on price stability is questioned. The objectives of central banks are considered to be insufficiently geared towards detecting and addressing system risks. ${ }^{70}$ To be sure, the primarily economic debate on the contribution of central banks to the global financial crisis is far from conclusive. Nevertheless it seems appropriate to raise the issue of possible legal consequences for the future position and tasks of central banks and namely, whether and to what extent the monetary policy objective should be geared towards or include aims other than price stability, and to what extent central banks should play a more active role in (macro-) prudential supervision. ${ }^{71}$

Central banks may find themselves faced with demands for the inclusion in their legal bases of new or the extension of existing objectives and tasks linked to prudential supervision. As the separation of the monetary policy from the financial regulatory and supervisory tasks are believed to have contributed to a one-sided focus on inflation, ${ }^{72}$ a more prominent role for central banks in monitoring systemic risks is suggested. Thus for example the Larosière Report recommends that central banks ". . . should receive an explicit formal mandate to assess high-level macrofinancial risks to the system and to issue warnings where required." ${ }^{73}$ From a legal

\footnotetext{
${ }^{68}$ The High-Level Group on Financial Supervision in the EU (Larosière Report), chaired by J. de Larosière, 25 February 2009, p. 7; for a brief assessment of the contribution of the U.S. subprime mortgages market to the financial crisis see Ohler, International Regulation and Supervision of Financial Markets after the Crisis, Working Papers on Global Financial Markets No. 4, March 2009 , pp. 5 et seq; see also the remarks by the Governor of the Bank of Japan: Shirakawa, Revisiting the Philosophy behind Central Bank Policy, Speech at the Economic Club of New York, 22 April 2010, available at http://www.boj.or.jp/en (last accessed 24 April 2010), p. 5, who openly wonders: "For me, the key question, which applies to many central banks including both the Bank of Japan and the Federal Reserve, is that, why we, as central banks, maintained interest rates at such a low level, in spite of the uneasiness we felt at that time toward the bubble-like symptoms."

${ }^{69}$ Roberts, The Failure of the Guardians: Central Banking Reform and the Financial Crisis, Suffolk University Law School Legal Studies Research Paper Series, Research Paper 09-54, 21 December 2009, p. 17, who observes that "Central bank independence was not justified as a technique for protecting systemic stability", but rather, "an anti-inflation regime".

${ }^{70}$ See e.g. Frisell/Roszbach/Spagnolo, Governing the Governors: A Clinical Study of Central Banks, Sveriges Riksbank Research Paper Series No. 54, March 2008, p. 8; Shirakawa, Revisiting the Philosophy behind Central Bank Policy, Speech at the Economic Club of New York, 22 April 2010, available at http://www.boj.or.jp/en (last accessed 24 April 2010), pp. 7-8.

${ }^{71}$ On the terminology see Clement, The term "macro prudential": origins and evolution, BIS Quarterly Review, March 2010, p. 59.

${ }^{72}$ Shirakawa, Revisiting the Philosophy behind Central Bank Policy, Speech at the Economic Club of New York, 22 April 2010, available at http://www.boj.or.jp/en (last accessed 7 May 2010), pp. 5-6.

${ }^{73}$ The High-Level Group on Financial Supervision in the EU (Larosière Report), chaired by J. de Larosière, 25 February 2009, p. 44.
} 
point of view it takes little to include financial stability as another central bank (monetary) objective in particular since many central bank laws in principle already recognise a role of the central bank in monitoring developments in this regard. ${ }^{74}$ However, objections are the feasibility of assigning a system stability objective to central banks and the effects which the taking on of supervisory tasks may have on the independence of monetary policy (operations).

Including a system stability objective in the legal basis of a central bank raises the question exactly what the position of such an additional mandate should be next to the existing primary objective currently found in many central bank laws. Should it be given priority, placed on an equal footing with price stability or come as a secondary objective? As has been observed above multiple central bank objectives may not only be problematic from the point of view of accountability, but come at the expanse of the effective conduct of any price stability objective. The latter of course assumes the existence of a trade-off between price stability and a system stability objective. This is however far from undisputed. Calling for the inclusion of an explicit system stability objective also suggested that the price stability objective is not sufficient in this regard. However, Issing has argued that “... if the central bank employs a medium term horizon for the definition of price stability and implies a strategy encompassing a stability-oriented, forward-looking approach, financial imbalances will implicitly obtain the attention they deserve. This is true even if financial stability is not considered a general objective of the central bank and monetary policy aims at maintaining the objective of price stability. [...] In most cases price stability would foster financial stability" ${ }^{75}$ Supporting this view past research suggests that "... price level instability also contributed to financial instability historically". ${ }^{76}$ Yet other factors also contribute to financial stability. ${ }^{77}$ In fact it has been acknowledged that ". . . financial imbalances can build up even in an environment of stable prices" $" 78$ Moreover, even if a system stability objective is provided for, given the nature of the subject-matter, this could hardly amount to a precise or even quantified objective. This is highlighted by the

\footnotetext{
${ }^{74}$ See e.g. Art. 127(5) TFEU and Art. 3.3. of the Protocol on the Statute of the European System of Central Banks and of the European Central Bank, OJ 2008 C 115/230, according to which the ESCB shall contribute to the smooth conduct of policies pursued by the competent authorities relating to the prudential supervision of credit institutions and the stability of the financial system.

${ }^{75}$ Brackets added and footnote omitted; Issing, Monetary and Financial Stability: Is there a Tradeoff?, Speech presented at the conference on "Monetary Stability, Financial Stability and the Business Cycle", 28-29 March 2003, Bank for International Settlements, available at http:// www.ecb.int (last accessed 7 May 2010). Issing does acknowledge the possibility of short-term conflicts "in rare circumstances".

${ }^{76}$ Bodo/Wheelock, Price Stability and Financial Stability: The Historical Record, Federal reserve Bank of St. Louis Review, September/October 1998, pp. 41 et seq. (60).

${ }^{77}$ See Trichet, Laudatio for Hans Tietmeyer, Speech held on 26 March 2010, available at http:// www.ecb.int (last accessed 7 May 2010).

${ }^{78}$ Issing, Monetary and Financial Stability: Is there a Trade-off?, Speech presented at the conference on "Monetary Stability, Financial Stability and the Business Cycle", 28-29 March 2003, Bank for International Settlements, available at http://www.ecb.int (last accessed 7 May 2010).
} 
objectives in the legal bases of existing regulatory and supervisory agencies outside central banks, where general references to preserving the stability of the financial system or to maintaining market stability and at times even multiple objectives linked to financial stability can be found. ${ }^{79}$ Judging a central bank's performance based on such broad objectives is difficult beyond generally noting the absence of financial instability and/or insolvent financial institutions. ${ }^{80}$

What is more, calls for a greater role in monitoring system stability imply that central banks can actually effectively detect systemic risks and act upon them with the instruments currently at their disposal. In defence of placing these tasks with the central bank it can be argued that "... synergies can be achieved by combining information gained from prudential supervision and from the conduct of monetary policy, the overall responsibility of the central bank for the stability of the system as a whole and the independence position of central banks and technical expertise existing therein, are all arguments in favour of vesting this task in the central bank." ${ }^{81}$ Applying a similar economy-of-scale argument the Larosière Report emphasizes that "... the role of central banks which are by essence well placed to observe the first signs of vulnerability of a bank is of crucial importance." 82 As concerns the ability of a central bank to fulfill such a task, Issing notes that "The uncertainty related to the identification of an asset price bubble is not fundamentally different from the uncertainty surrounding other variables, in which the central bank bases its policy decisions." ${ }^{83}$ At the same time, against the background of the housing bubble both Issing, as well as Posen question the ability of central banks to effectively intervene once systemic risks have actually been detected. Posen observes that the tightening of monetary policy in response to such developments "in no way substitutes for directly dealing with the underlying financial problems" while at the same time producing costs for the real economy. ${ }^{84}$ Yet, even if

\footnotetext{
${ }^{79}$ Exemplary in this regard are the five statutory objectives laid down for the UK Financial Services Authority in the Financial Service and Markets Act 2000.

${ }^{80}$ With regard to the usefulness of such broad objectives for accountability purposes, see e.g. Hüpkes/Quintyn/Taylor, The Accountability of Financial Sector Supervisors: Principles and Practice, IMF Working Paper WP/05/51, 2005.

${ }^{81}$ Amtenbrink, Economic, Monetary and Social Policy, in: McDonnell/Kapteyn/Mortelmans/ Timmermans (eds.), The Law of the European Union and the European Communities, (4th ed.) 2008 , pp. 881 et seq. (972), with further references.

${ }^{82}$ The High-Level Group on Financial Supervision in the EU (Larosière Report), chaired by J. de Larosière, 25 February 2009, pp. 7 et seq.

${ }^{83}$ Issing, Monetary and Financial Stability: Is there a Trade-off?, Speech presented at the conference on "Monetary Stability, Financial Stability and the Business Cycle", 28-29 March 2003, Bank for International Settlements, available at http://www.ecb.int (last accessed 7 May 2010).

${ }^{84}$ Posen, Why Central Banks Should Not Burst Bubbles, Peterson Institute for International Economics Working Paper Series WP 06/1, January 2006, p. 11, who argues that “... the connection between monetary conditions and the rise of bubbles is rather tenuous, and by raising interest rates a central bank is unlikely to achieve what is needed - i.e., persuading investors that the bubble is ill-founded and/or that they will not find some greater fool to sell to in time."; see also Issing, Monetary and Financial Stability: Is there a Trade-off?, Speech presented at the conference
} 
monetary policy may not provide the necessary instruments to intervene, this is not to say that central banks are per se unsuitable for the job. In this regard much depends on the legal arrangements governing micro-prudential supervision and, to the extent that this task is placed (partially) outside the central bank, on the extent to which the central bank cooperates with the competent financial regulatory and (other) supervisory authorities. In case of a separation of tasks the role of the central bank may be primarily that of monitoring and informing/advising the competent agencies on systemic risks and how to address them.

Assigning prudential supervisory tasks to a central bank may not be entirely unproblematic. Indeed, monetary policy and prudential supervision are somewhat uneasy bedfellows. ${ }^{85}$ While it may be argued that as a lender of last resort central banks should in principle be in a perfect position to monitor financial stability and to judge whether financial institutions are actual insolvent or simply in need of liquidity, Di Noia and Di Giorgio with reference to work by Goodhart and Schoenmaker conclude that: “... this argument does not hold, in the sense that the 'revealed preferences' of monetary authorities have been to 'rescue banks running into difficulties so long as there appeared to be any risk of a systemic knock-on effect'," 86

Assigning multiple tasks to the central bank can give rise to perverse incentives on parts of the central bank that may be tempted to (ab-) use monetary policy as a tool to fulfil its role as supervisor, resulting in biased policy decisions. ${ }^{87}$ Supporting this view, empirical evidence points to a positive correlation between the placement of all banking supervisory tasks at the central banks and the rate and volatility of inflation in countries. ${ }^{88}$ However, one should be careful not to conclude from this

on "Monetary Stability, Financial Stability and the Business Cycle", 28-29 March 2003, Bank for International Settlements, available at http://www.ecb.int (last accessed 7 May 2010), who raises doubts as to the ability of central banks to detect such bubbles in real time.

${ }^{85}$ See generally on this issue Schoenmaker, Institutional Separation Between Supervisory and Monetary Agencies, FMG Special papers No. 52, Financial Markets Group Research Centre, 1992; Di Noia/Di Giorgio, Should Banking Supervision and Monetary Policy Tasks be Given to Different Institutions?, International Finance 3 (1999) 2, pp. 361 et seq. (368 et seq.); ECB, The Role of Central Banks in Prudential Supervision, Position Paper, 2001, available at http://www. ecb.int (last accessed 7 May 2010); in the European context see also Smits, The European Central Bank: Institutional Aspects, 1997, pp. 310-327; Andenas/Hadjiemmanuel, Banking Supervision, The Internal Market and European Monetary Union, in: Andenas et al. (eds.), European Economic and Monetary Union: the Institutional Framework, 1997, pp. 371 et seq. (386-394); an instructive overview of the arguments is provided in a position paper by the European Central Bank: The Role of Central Banks, 2001, in particular p. 3-7.

${ }^{86}$ Di Noia/Di Giorgio, Should Banking Supervision and Monetary Policy Tasks be Given to Different Institutions?, International Finance 3 (1999) 2, pp. 361 et seq. (368), with reference to Goodhart/Schoenmaker, Should the functions of monetary policy and banking supervision be separated?, Oxf. Econ. Pap. 47 (1995) 4, p. 539.

${ }^{87}$ Tuya/Zamalloa, Issues on Placing Banking Supervision in the Central Bank, in: Balino/Cottarelli (eds.), Frameworks for Monetary Stability, 1994, pp. 663 et seq. (679).

${ }^{88}$ Di Noia/Di Giorgio, Should Banking Supervision and Monetary Policy Tasks be Given to Different Institutions?, International Finance 3 (1999) 2, pp. 361 et seq. (376). 
that central banks should not at all be involved in prudential supervision. In fact what is missing in debates on this topic is a clear differentiation between macroand micro-prudential supervisory tasks and thus, the task of ensuring the stability of the financial system as a whole and the task of ensuring the safety of the banking system (banking supervision). Indeed, the concerns about possible conflicts of interests may be primarily linked to the latter function. It is at least not evident why reinforced rules on the monitoring of financial stability and, where necessary, a formal obligation to informing and advice competent regulatory and supervisory agencies would be a major problem in this regard. Understood in such away, macroprudential supervision does not have to be at odds with the independent position of a central bank or its primary monetary policy objective. Anything beyond such a role however can create conflicts of interest and, in the case of a bad handling of a crisis moreover result in reputational damage with effects also for monetary policy. The vesting of extensive supervisory or even regulatory powers would also result in a further accumulation of powers in what is already a major independent policy maker - in many instances - effectively remote from the constitutional system of checks and balances.

The integrated financial systems call for a global assessment of their stability. Yet, any one central bank system arguably cannot make this assessment without proper information. Thus, cooperation between central banks takes place through an array of formal and informal international networks. ${ }^{89}$ This cooperation takes place inter alia through the Financial Stability Board, ${ }^{90}$ the before mentioned Central Bank Governance Forum ${ }^{91}$ and the Central Bank Governance Network. ${ }^{92}$ This also extents to global financial markets and to micro-prudential supervision. The coordination and exchange of information is just as important as the establishment of global standards and best practice. Once again the EU can serve as an example for system providing for a such coordination, albeit being far from ideal in this regard.

The role of the ECB in prudential supervision as described in the TFEU and the Protocol on the ESCB and on the ECB is essentially limited to that of an advisor to the Council, the European Commission and the competent authorities of the Member States relating to the prudential supervision of credit institutions and to the stability of the financial system as a whole. ${ }^{93}$ Financial market supervision is

\footnotetext{
${ }^{89}$ On central banks as network institutions, see Marcusson, The transnational governance network of central bankers, in: Djelic/Sahlin-Anderson (eds.), Transnational Governance. Institutional Dynamics of Regulation, 2006, pp. 180 et seq. (191 et seq.).

${ }^{90}$ Successor to the Financial Stability Forum. It brings together namely representatives from national governments, central banks and supervisory agencies.

${ }^{91}$ Selected group of central bank governors that exchange views on the design and operation of central banks.

${ }^{92}$ Forum bringing together central bank governors to exchange views on issues of central bank governance with the Bank for International Settlements.

${ }^{93}$ Smits, The European Central Bank: Institutional Aspects, 1997, pp. 339-343, 353. In this context Smits criticises the fact that the Protocol on certain provisions relating to the United
} 
effectively in the hands of the national competent authorities of the Member States which in some, but certainly not all instances are the national central bank. Under the current EU Lamfalussy framework no centralization, but rather a coordination of supervisory tasks, namely through the Level 2 and Level 3 committees takes place. The difficulties of coordinating supervisory efforts in such a decentralised system have been extensively discussed in the relevant literature. ${ }^{94}$

The absence of a prudential supervision task of the ECB may be historically explained by the reluctance of national governments (and indeed their central banks) to vest also supervisory tasks upon a supranational independent monetary policy authority, resulting not only in an accumulation of power, but also a further loss of tasks for national central banks to perform. ${ }^{95}$ This may also explain why the enabling clause of ex Art. 105(6) EC which allowed for the transfer to the ECB of specific tasks concerning policies relating to the supervision of credit institutions and other financial firms excluding insurance undertakings has never been activated. In fact the provision has been left unchanged by the Treaty of Lisbon which does not vest any new supervisory powers in the ECB. ${ }^{96}$

In the wake of the global financial crisis the European Commission has revisited the existing Union framework and made concrete proposals to reinforce financial supervision. $^{97}$ The several legislative proposals address both macro- as well as micro-prudential supervision of the financial markets. From the outset it is noteworthy that none of these proposals aim at outright placing macro- or microprudential supervision at the ECB. Instead, on the micro-prudential side the European Commission proposes the establishment of a European System of Financial Supervisors (ESFS), consisting of a network of national financial supervisors working in cooperation with three new regulatory agencies, including a European Banking Authority, a European Insurance and Occupational Pensions Authority and a European Securities and Markets Authority. ${ }^{98}$ While placed outside the ECB,

Kingdom and the Protocol on certain provisions relating to Denmark for excluding this role of the ECB. This may be particularly problematic in the case of the United Kingdom as the most important European financial capital.

${ }^{94}$ E.g. Lastra, Central Banking and Banking Regulation, 1996, with further references.

${ }^{95}$ See Smits, The European Central Bank: Institutional Aspects, 1997, pp. 334-338.

${ }^{96}$ Now Art. 127(6) TFEU.

${ }^{97}$ European Commission adopts legislative proposals to strengthen financial supervision in the EU, Press release of 23 September 2009, IP/09/1347.

${ }^{98}$ Proposal for a regulation of the European Parliament and of the Council establishing a European Banking Authority, COM(2009) 501 final; Proposal for a regulation of the European Parliament and of the Council establishing a European Insurance and Occupational Pensions Authority, $\operatorname{COM}(2009) 502$ final; Proposal for a regulation of the European Parliament and of the Council establishing a European Securities and Markets Authority, COM(2009) 503 final; see also Proposal for a Directive of the European Parliament and of the Council Amending Directives 1998/26/EC, 2002/87/EC, 2003/6/EC, 2003/41/EC, 2003/71/EC, 2004/39/EC, 2004/109/EC, 2005/60/EC, 2006/48/EC, 2006/49/EC, and 2009/65/EC in respect of the powers of the European Banking Authority, the European Insurance and Occupational Pensions Authority and the European Securities and Markets Authority, $\operatorname{COM(2009)} 576$ final. 
close institutional links primarily with the future European Banking Authority are foreseen through the participation, albeit in a non-voting capacity, of an ECB representative.

As far as macro-prudential supervision is concerned the European Commission has proposed the establishment of a European System Risk Board (ESRB). ${ }^{99}$ The ESRB would be established as an EU regulatory agency and thus be formally placed outside the ECB. Nevertheless, the envisaged composition of the main decision-making body highlights the close link to the ECB, the national central banks and the national supervisory authorities all of which would make up the majority of the members of the General Board of the ESRB. ${ }^{100}$ Moreover, it is planned to situate the secretariat of the ESRB at the seat of the ECB, so that synergies can emerge between these two bodies. The ESRB would be responsible for the macro-prudential oversight of the EU financial system "... in order to prevent or mitigate systemic risks within the financial system, so as to avoid episodes of widespread financial distress, contribute to a smooth functioning of the Internal Market and ensure a sustainable contribution of the financial sector to economic growth." ${ }^{101}$ For this purpose the ESRB would not only be charged with identifying and prioritizing such risks, but in the case of the emergence of significant risks to issue warnings and even recommendations for remedial action. ${ }^{102}$ Addressee of these warnings and recommendations could be the EU as a whole, the proposed European regulatory agencies, Member States or national supervisory authorities. ${ }^{103}$ Moreover, it is foreseen that the ESRB cooperates with international institutions such as the IMF. All in all, namely the initiative to establish an ESRB highlights the recognition in the EU of the need for more effective mechanisms to prevent the emergence of a global financial crisis of the proportions which can currently be witnessed.

\section{Concluding Remarks}

Ever since their emergence as sole issuer of currency, the role of central banks has constantly evolved accommodating both for the development of (international) trade and the understanding of the fundamentals of the economy. With the emergence of regional economic cooperation namely in the second half of the twentieth

\footnotetext{
${ }^{99}$ Proposal for a Regulation of the European Parliament and of the Council on Community macro prudential oversight of the financial system and establishing a European Systemic Risk Board, $\operatorname{COM}(2009) 499$ final; Proposal for a Council Decision entrusting the European Central Bank with specific tasks concerning the functioning of the European Systemic Risk Board, $\operatorname{COM}(2009) 500$ final.

${ }^{100}$ Ibid., Art. 4(1), (2) and Art. 6.

${ }^{101}$ Ibid., Art. 3(1).

${ }^{102}$ Ibid., Art. 15-18.

${ }^{103}$ Ibid., Art. 16(2).
} 
century and the gradual opening of domestic markets which increasingly has turned into a global phenomenon, more than ever before in their history central banks find themselves influenced by global trends and developments both in their institutional set-up and their main monetary policy task.

More so than national regulators and policy makers the institutional characteristics and main monetary policy objectives are decided by global financial markets on whose trust central banks rely. This is facilitated by the drafting by international standard setting organisations, such as the IMF, of guidelines and codes of best practice. The lattor has resulted in a de facto synchronization of the main institutional features and monetary tasks. Yet, in particular the unisono focus on price stability has been criticised in the aftermath of the global financial crisis for having contributed to a general failure by central banks to detect system risks.

In pursuing monetary policy in a global environment central banks may in fact be much less independent in the conduct of monetary policy than their statutory legal bases and - at times - regulators and policy makers suggest. This is not only true but certainly also true in times of global financial crisis. Next to government interventions, central banks have played a major role in adding liquidity to the financial market and by guaranteeing (government) debts. ${ }^{104}$ Central banks could be seen relaxing their monetary policies stands, whereby in some instances conventional monetary policy reached its outer limits. Roberts predicts that as a result of the role of central banks in the financial crisis "... it seems probable that skepticism about technocratic governance and about the trustworthiness of markets will encourage the reassertion of political influence in policy domains that were, in the heyday of liberalization, the preserve of technocrat-guardians."105 Translated to the position of central banks this suggests that public and eventually political pressure may grow to revisit the position of monetary policy authorities outside government. However, it is unclear in exactly what ways the involvement of elected politicians and government officials under the direct influence of the former would be an improvement upon the current situation or would have prevented the crisis. As far as monetary policy is concerned, in the absence of any evidence suggesting

\footnotetext{
${ }^{104}$ For an early overview of the role of central banks in dealing with the global financial crisis, see Bank for International Settlements Committee on the Global Financial System, Central bank operations in response to the financial turmoil, Report submitted by a Study Group established by the Committee, July 2008, available at http://www.bis.org (last accessed 7 May 2010); Papademos, How to deal with the global financial crisis and promote the economy's recovery and sustained growth, Speech held at the 7th European Business Summit organised by the European Business Forum, 26 March 2009, available at http://www.ecb.int (last accessed 7 May 2010); Roth, Challenges for Central Banks during the Current Global Crisis, address at the occasion of the Sixth Annual NBP-SNB Joint Seminar on "Challenges for Central Banks during the Current Global Crisis", 15 June 2009, available at http://www.snb.ch/n/mmr/reference/ sem_2009_06_14_speech/source (last accessed 7 May 2010).

${ }^{105}$ Roberts, The Failure of the Guardians: Central Banking Reform and the Financial Crisis, Suffolk University Law School Legal Studies Research Paper Series, Research Paper 09-54, 21 December 2009, p. 25.
} 
that the theoretical and empirical foundation of the current institutional arrangements, i.e. the negative correlation between central bank independence and inflation and inflation variability, is obsolete changing the institutional position of central banks would simply increase political influence without any major benefits.

All the same time, the financial crisis should be seen as an opportunity to seriously re-evaluate the role of central banks as monetary policy authorities in a global economy. In doing so it should be taken into consideration that, a simple proliferation of central bank tasks does not necessarily make their role any more effective or indeed straightforward. 
http://www.springer.com/978-3-642-14431-8

European Yearbook of International Economic Law 2011

(Eds.)C. Herrmann; J.P. Terhechte 2011, XVII, 520 p., Hardcover

ISBN: $978-3-642-14431-8$ 